\title{
Impact of accelerated future global mean sea level rise on hypoxia in the Baltic Sea
}

\author{
H. E. M. Meier ${ }^{1,2}\left(\mathbb{0} \cdot\right.$ A. Höglund ${ }^{2} \cdot$ K. Eilola $^{2} \cdot$ E. Almroth-Rosell ${ }^{2}$
}

Received: 23 March 2016 / Accepted: 23 August 2016 / Published online: 27 August 2016

(c) The Author(s) 2016. This article is published with open access at Springerlink.com

\begin{abstract}
Expanding hypoxia is today a major threat for many coastal seas around the world and disentangling its drivers is a large challenge for interdisciplinary research. Using a coupled physical-biogeochemical model we estimate the impact of past and accelerated future global mean sea level rise (GSLR) upon water exchange and oxygen conditions in a semi-enclosed, shallow sea. As a study site, the Baltic Sea was chosen that suffers today from eutrophication and from dead bottom zones due to (1) excessive nutrient loads from land, (2) limited water exchange with the world ocean and (3) perhaps other drivers like global warming. We show from model simulations for the period 1850-2008 that the impacts of past GSLR on the marine ecosystem were relatively small. If we assume for the end of the twenty-first century a GSLR of +0.5 m relative to today's mean sea level, the impact on the marine ecosystem may still be small. Such a GSLR corresponds approximately to the projected ensemble-mean value reported by the Fifth Assessment Report of the Intergovernmental Panel on Climate Change. However, we conclude that GSLR should be considered in future high-end projections $(>+1 \mathrm{~m})$ for the Baltic Sea and other coastal seas with similar hydrographical conditions as in the Baltic because GSLR may lead to reinforced saltwater inflows causing higher salinity and increased vertical stratification compared to present-day conditions. Contrary to intuition,
\end{abstract}

H. E. M. Meier

markus.meier@io-warnemuende.de

1 Department of Physical Oceanography and Instrumentation, Leibniz Institute for Baltic Sea Research Warnemünde, 18119 Rostock, Germany

2 Department of Research and Development, Swedish Meteorological and Hydrological Institute, 60176 Norrköping, Sweden reinforced ventilation of the deep water does not lead to overall improved oxygen conditions but causes instead expanded dead bottom areas accompanied with increased internal phosphorus loads from the sediments and increased risk for cyanobacteria blooms.

Keywords Coastal seas - Baltic Sea $\cdot$ Numerical modeling $\cdot$ Climate change $\cdot$ Global mean sea level rise . Marine biogeochemical cycles $\cdot$ Hypoxia

\section{Introduction}

Changing climate may have considerable impact on coastal seas, like the Baltic Sea (BACC II author team 2015) and North Sea (Quante and Colijn 2016). Especially the Baltic Sea is known to have warmed during 1982-2006 faster than any other coastal sea (Belkin 2009). For the end of this century higher water temperatures, reduced sea ice cover, increased acidification and increased oxygen deficiency with consequently larger hypoxic areas (or dead bottom zones) are expected (e.g., Döscher and Meier 2004; Meier et al. 2011; Neumann et al. 2012; Omstedt et al. 2012). In particular, the latter is problematic as the Baltic Sea holds already today the world's largest oxygen depleted, dead zone caused by human influence (e.g., Conley 2012). Although available scenario simulations show a tendency towards reduced salinities (Meier et al. 2006, 2011), it is still uncertain whether the Baltic Sea will become less or more saline because of the large bias in precipitation and evaporation of regional climate models (Meier 2015). The salinity in the Baltic Sea, which is a semi-enclosed boreal sea with limited water exchange with the world ocean (Fig. 1), is controlled by a large freshwater supply mainly from rivers (Bergström and Carlsson 


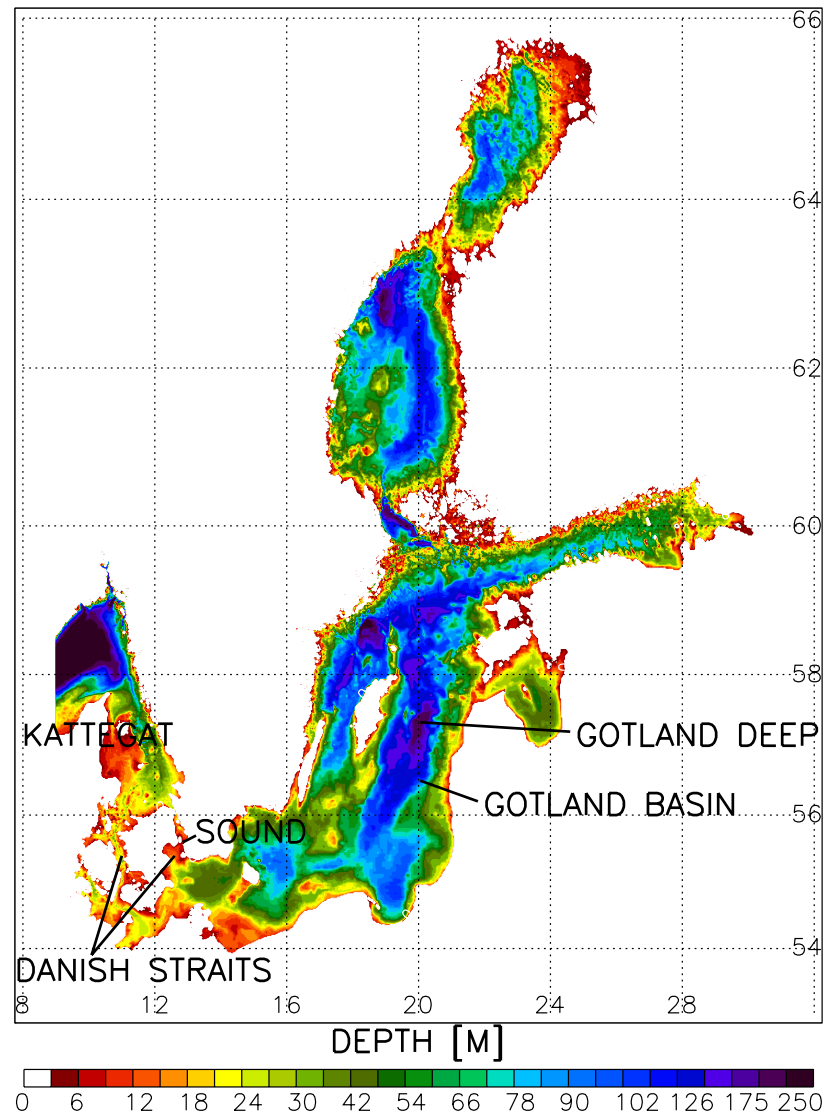

Fig. 1 Bottom topography of the Baltic Sea and the location of Gotland Deep

1994) and by saltwater inflows across the sills (located in the Danish straits) separating the Baltic Sea from the adjacent Kattegat and North Sea. Hence, the long-term mean (1902-1998) salinity averaged for the Baltic Sea without Kattegat amounts to only $7.4 \mathrm{~g} \mathrm{~kg}^{-1}$ (Meier and Kauker 2003). Small- and medium-size inflows occur relatively regularly but large inflows are intermittent and usually weather driven events (Matthäus et al. 2008). Only the large saltwater inflows, so-called Major Baltic Inflows (MBIs), ventilate the Baltic deep water with high-saline and oxygen-rich water on time scales of one to ten years (Matthäus et al. 2008; Eilola et al. 2014; Mohrholz et al. 2015; Gräwe et al. 2015). MBIs occur mainly during winter but a few events have been observed in spring and autumn as well (Matthäus and Franck 1992; Fischer and Matthäus 1996). Prerequisite of an MBI is a period of easterly winds lasting for about 20 days that lower the sea level in the semi-enclosed Baltic Sea (Lass and Matthäus 1996). After the so-called precursory period of an MBI strong to very strong westerly winds of similar duration force saline water from the Kattegat over the shallow sills into the Baltic Sea. Although the meteorological conditions responsible for MBIs are projected to occur more often (Schimanke et al.
2014), projections suggest reduced salinity at the end of the century (Meier et al. 2006, 2011) due to the overwhelming impact of increased runoff. The latter is a consequence of the enhanced hydrological cycle in the northern Baltic catchment area in the climate models (Sonnenborg 2015).

However, in all scenario simulations performed so far one effect has not been considered, the global mean sea level rise (GSLR) which may cause an increased flow of saltwater into the Baltic Sea due to increased water depth in the Danish straits (e.g., Gustafsson 2004; Hordoir et al. 2015; Arneborg 2016). According to the Fifth Assessment Report of the Intergovernmental Panel on Climate Change (IPCC 2013) global mean sea level has risen by about +0.19 m over the period 1901-2010 and is projected to rise further during this century (Church et al. 2013). Depending on the applied global general circulation model (GCM) and representative concentration pathway (RCP) the GSLR for 2081-2100 is projected to be in the range of +0.26 to +0.82 m relative to 1986-2005 (Church et al. 2013). For $\mathrm{RCP} 8.5$, the rise by the year 2100 is even in the range of +0.52 to $+0.98 \mathrm{~m}$. Semi-empirical model projections of GSLR are even higher (e.g., Pfeffer et al. 2008; Rahmstorf 2007) but whether these semi-empirical projections are physically plausible is a matter of debate. In general, projections of GSLR are very uncertain because the reaction of ice sheets to global warming is poorly known. Nevertheless, GSLR of about one meter at the end of this century might be possible (Church et al. 2013). From paleoclimate studies it is known that due to the interplay between land uplift and GSLR a larger cross section in the Sound (for location see Fig. 1) 6000 years ago caused much higher salinity in the Baltic than today (Gustafsson and Westman 2002). Indeed, there is evidence from sediment cores that in the Baltic Sea during that time and during other periods in the past hypoxia prevailed (Zillén et al. 2008, Zillén and Conley 2010). However, whether the higher salinity was the driver of past hypoxia is unknown.

GSLR may have significant consequences for the Baltic Sea ecosystem because larger salt water flow across the shallow sills in the Danish straits will result in higher salinity in the Baltic Sea (Gustafsson 2004) and in stronger vertical stratification (Meier 2005) affecting vertical nutrient flow. Especially internal phosphorus fluxes between the sediment and the water column are known to be oxygen and hence stratification dependent (e.g., Conley et al. 2009). However, whether the Baltic Sea will be more or less saline in future climate will depend on several competing drivers, like changes in river runoff, changes in wind patterns, GSLR and land uplift. In the northern Baltic land uplift might exceed or in the case of high-end scenarios neutralize GSLR whereas land uplift in the entrance area of the Baltic Sea is negligible on a 100-year time scale (Ekman 1996). 
So far GSLR was neglected in both long hindcast and transient scenario simulations of the Baltic Sea because the effect was assumed to be small (e.g., Meier et al. 2006, 2011, 2012). However, the impact of GSLR has never been quantitatively assessed. From other coastal seas like Chesapeake Bay a statistically significant increase of salinity due to past sea level rise was reported (Hilton et al. 2008). In this study, for the first time the potential impact of past and accelerated future GSLR on stratification, phosphorus cycling and eutrophication is investigated using a coupled physical-biogeochemical model for the Baltic Sea (Meier et al. 2003; Eilola et al. 2009). The study is timely because within the BONUS BalticAPP project (http://www.bonusportal.org/projects/research_projects/balticapp) new scenario simulations based upon IPCC (2013) are under development.

\section{Method}

We use the three-dimensional coupled physical-biogeochemical model RCO-SCOBI which consists of the physical Rossby Centre Ocean (RCO) model (Meier et al. 2003) and the Swedish Coastal and Ocean Biogeochemical (SCOBI) model (Eilola et al. 2009; Almroth-Rosell et al. 2011). RCO-SCOBI has been previously evaluated and applied for numerous long-term climate studies (e.g., Meier and Kauker 2003; Meier et al. 2003, 2011, 2012).

Within RCO the ocean circulation model is coupled to a Hibler-type sea ice model and the subgrid-scale mixing in the ocean is parameterized using a $\mathrm{k}-\varepsilon$ turbulence closure scheme with flux boundary conditions (Meier et al. 2003). A flux-corrected, monotonicity preserving transport (FCT) scheme is embedded without explicit horizontal diffusion. In the northern Kattegat (Fig. 1) open lateral boundary conditions are used, where in case of inflow temperature and salinity values are nudged towards observed climatological profiles and in case of outflow a modified Orlanski radiation condition is used. Horizontal and vertical resolutions amount to $3.7 \mathrm{~km}$ and $3 \mathrm{~m}$, respectively. For further details, the reader is referred to Meier et al. (2003).

SCOBI describes the dynamics of nitrate, ammonium, phosphate, three phytoplankton species, zooplankton, detritus, oxygen and hydrogen sulfide (Eilola et al. 2009). The sediment contains nutrients in the form of benthic nitrogen and benthic phosphorus. Processes like assimilation, remineralization, nitrogen fixation, nitrification, denitrification, grazing, mortality, excretion, sedimentation, resuspension and burial are considered. With the help of a simplified wave model resuspension of organic matter is calculated (Almroth-Rosell et al. 2011). For further details and an evaluation of the SCOBI model the reader is referred to Eilola et al. (2009, 2011) and Almroth-Rosell et al. (2011).
The baseline of this study is a historical simulation for the period 1850-2008 using reconstructed atmospheric, hydrological and nutrient load forcing and daily sea levels at the lateral boundary as described by Gustafsson et al. (2012) and Meier et al. (2012). In the following, a brief summary of the forcing data is provided. Using regionalized reanalysis data for 1957-2007 together with historical station data of daily sea-level pressure and monthly air temperature observations, multivariate daily atmospheric forcing fields were reconstructed based upon the analogmethod (Schenk and Zorita 2012). For the calculation of monthly mean river flows three data sets were merged. For 1850-1900, 1901-2004, 2005-2008 reconstructions by Hansson et al. (2011) and by Meier and Kauker (2003) and hydrological model data by Graham (1999) were used, respectively. For 1970-2006, nutrient loads from rivers and point sources were compiled from the Baltic Environmental and HELCOM databases (Savchuk et al. 2012). Estimates of pre-industrial loads for 1900 are based upon Savchuk et al. (2008). Between these two environmental states nutrient loads were linearly interpolated between selected reference years taking the intensified agriculture since the 1950s into account. Similarly, atmospheric loads were estimated (Ruoho-Airola et al. 2012). Nutrient loads contain both organic and inorganic phosphorus and nitrogen, respectively. Sea level elevations at the lateral boundary were calculated from the reconstructed, meridional sea level pressure gradient across the North Sea following Gustafsson and Andersson (2001). To avoid the underestimation of extremes the correlations were calculated for various frequency bands using Empirical Orthogonal Functions (EOFs) (Gustafsson et al. 2012). Finally, initial conditions were estimated based upon Savchuk et al. (2008). After a spin-up simulation for 1850-1902 utilizing the reconstructed forcing as described above, the calculated physical and biogeochemical variables at the end of the spin-up simulation were used as initial condition for 1850 .

As we anticipate a long response time scale of the phosphorus cycle to GSLR (e.g., Gustafsson et al. 2012; Radtke et al. 2012), we chose a 159-year long simulation as reference (henceforth referred to as REF). In addition to REF, sensitivity experiments were carried out with the same setup as in REF but with externally prescribed, timeindependent sea level anomalies relative to present-day, mean sea surface height (SSH). For the simulated distribution of SSH the reader is referred to Meier et al. (2003). Technically the water depth in the entire model domain was increased or decreased depending on the change in global mean sea level and the thickness of the uppermost model layer was modified accordingly. Hence, in the sensitivity experiments only the mean sea level was altered whereas the temporal variability on all time scales remained unchanged compared to REF. 
Table 1 Changes in sea surface and bottom salinities at Gotland Deep $\left(\Delta \mathrm{SSS}\right.$ and $\Delta \mathrm{BS}$ in $\mathrm{g} \mathrm{kg}^{-1}$ ), volume averaged salinity of the entire Baltic Sea $\left(\Delta \mathrm{S}_{\text {ave }}\right.$ in both $\mathrm{g} \mathrm{kg}^{-1}$ and $\%$ of the mean salinity averaged for the entire Baltic Sea of $7.4 \mathrm{~g} \mathrm{~kg}^{-1}$ ), annual maximum hypoxic area ( $\triangle \mathrm{HA}$ in $\%)$ and volume averaged dissolved inorganic phosphate concentrations ( $\triangle \mathrm{DIP}$ in $\%$ ) in the sensitivity experiments, PAST, S50 and S100, with specified sea surface height anomalies $(\triangle \mathrm{SSH}$ in $\mathrm{m})$

\begin{tabular}{llllllllr}
\hline & $\Delta \mathrm{SSH}(\mathrm{m})$ & $\Delta \mathrm{SSS}\left(\mathrm{g} \mathrm{kg}^{-1}\right)$ & $\Delta \mathrm{BS}\left(\mathrm{g} \mathrm{kg}^{-1}\right)$ & $\Delta \mathrm{S}_{\mathrm{ave}}\left(\mathrm{g} \mathrm{kg}^{-1}\right)$ & $\Delta \mathrm{S}_{\mathrm{ave}}(\%)$ & $\Delta \mathrm{HA}(\%)$ & $(\Delta \mathrm{HA})_{\max }(\%)$ & $\Delta \mathrm{DIP}(\%)$ \\
\hline PAST & -0.24 & -0.33 & -0.45 & -0.35 & -5 & -2 & -8 & -3 \\
S50 & +0.5 & +0.68 & +0.90 & +0.71 & +10 & +4 & +19 & +5 \\
S100 & +1.0 & +1.34 & +1.75 & +1.41 & +19 & +7 & +43 & +9 \\
\hline
\end{tabular}

All figures are deviations from the long-term mean for the period 1988-2007. In addition, the maximum change in annual maximum hypoxic area in $1961\left[(\Delta \mathrm{HA})_{\max }\right.$ in $\left.\%\right]$ is listed

Past eustatic sea level rise in the Baltic Sea was estimated to be $1.5 \pm 0.53 \mathrm{~mm}_{\text {year }}{ }^{-1}$ (Gornitz 1995) or about $0.24 \mathrm{~m}$ during $1850-2008$. Hence, we investigate in a sensitivity experiment how biogeochemical cycling might have developed without the impact of past sea level rise assuming a $0.24 \mathrm{~m}$ lower sea level than today (henceforth referred to as PAST).

Further, we study how the projected future ensemblemean sea level rise of about $+0.5 \mathrm{~m}$ and a high-end scenario of about $+1 \mathrm{~m}$ compared to present-day sea level (Church et al. 2013) may affect biogeochemical cycling assuming nutrient loads and eutrophication status of the twentieth century. Henceforth, these sensitivity experiments mirroring perhaps sea level conditions at the end of the twenty-first century are referred to as $\mathrm{S} 50(+0.5 \mathrm{~m})$ and S100 $(+1.0 \mathrm{~m})$, respectively. In our sensitivity studies other possible changes of future climate like warming, increasing runoff and acidification are neglected.

\section{Results}

For sea level conditions as in 1850 with 0.24 m lower sea level as today (PAST) surface and bottom salinity changes relative to REF in 1988-2007 at Gotland Deep (for location see Fig. 1) amount to -0.3 and $-0.5 \mathrm{~g} \mathrm{~kg}^{-1}$, respectively (Table 1; Fig. 2). Note that salinity variations at Gotland Deep are representative for volume averaged salinity variations of the entire Baltic Sea. The corresponding salinity decrease averaged for the entire Baltic Sea amounts to $-0.4 \mathrm{~g} \mathrm{~kg}^{-1}$. As in REF the simulated mean salinity for 1988-2007 averaged for the entire Baltic Sea including Kattegat amounts to $7.4 \mathrm{~g} \mathrm{~kg}^{-1}$, which is close to the longterm mean calculated by Meier and Kauker (2003), ${ }^{1}$ the mean salinity decrease in PAST is about $-5 \%$. Correspondingly, relative changes of -5 and $-4 \%$ are

\footnotetext{
${ }^{1}$ Meier and Kauker (2003) estimated the long-term mean (19021998) salinity averaged for the Baltic Sea without Kattegat from a corrected, long-term simulation to be $7.36 \mathrm{~g} \mathrm{~kg}^{-1}$.
}

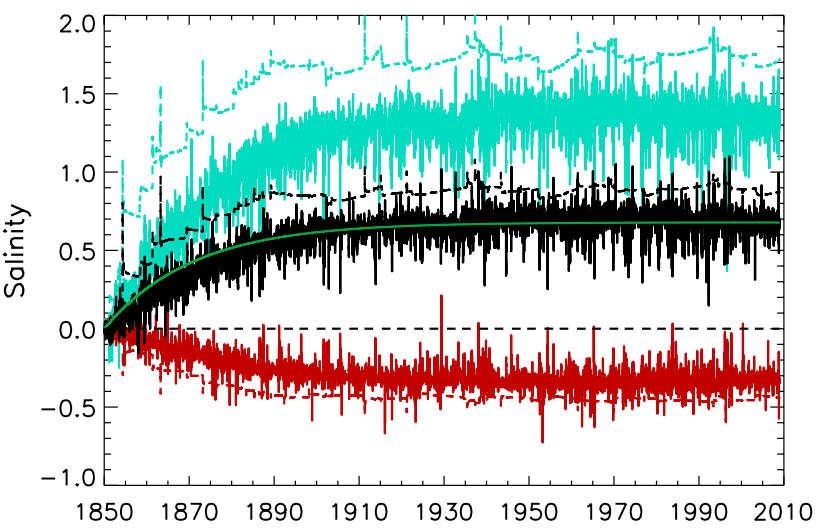

Fig. 2 Two-daily surface (solid lines) and bottom (dashed lines) water salinity differences at Gotland Deep between sensitivity and reference simulations: PAST (red lines), S50 (black lines) and S100 (blue lines). An exponential function with a time scale of 21 years is fitted to the surface salinity difference between S50 and REF (green line)

calculated for the above mentioned changes in surface and bottom salinities at Gotland Deep because in REF surface and bottom salinities averaged for 1988-2007 amount to 6.9 and $11.4 \mathrm{~g} \mathrm{~kg}^{-1}$, respectively. Past sea level rise had only little impact on present-day bottom oxygen concentrations (Fig. 3b, c). In PAST the mean (median) bottom oxygen concentration at Gotland Deep averaged for the entire period $1850-2008$ is only about $0.03(0.02) \mathrm{mL} \mathrm{L}^{-1}$ lower than in REF.

Applying a $0.5 \mathrm{~m}$ higher sea level (S50) causes surface and bottom salinities at Gotland Deep to increase by about 0.7 and $0.9 \mathrm{~g} \mathrm{~kg}^{-1}$ compared to REF, respectively (Table 1 ; Fig. 2), due to increased salt inflows. The corresponding salinity increase averaged for the entire Baltic Sea amounts to $0.7 \mathrm{~g} \mathrm{~kg}^{-1}$ or $10 \%$. Surface salinity changes are somewhat smaller than bottom salinity changes indicating an increase in stratification. The e-folding time scale of surface salinity changes at Gotland Deep as response to changes in saltwater inflows amounts to about 21 years (Fig. 2). This finding confirms earlier results of sensitivity experiments by Meier (2005) who investigated salinity 

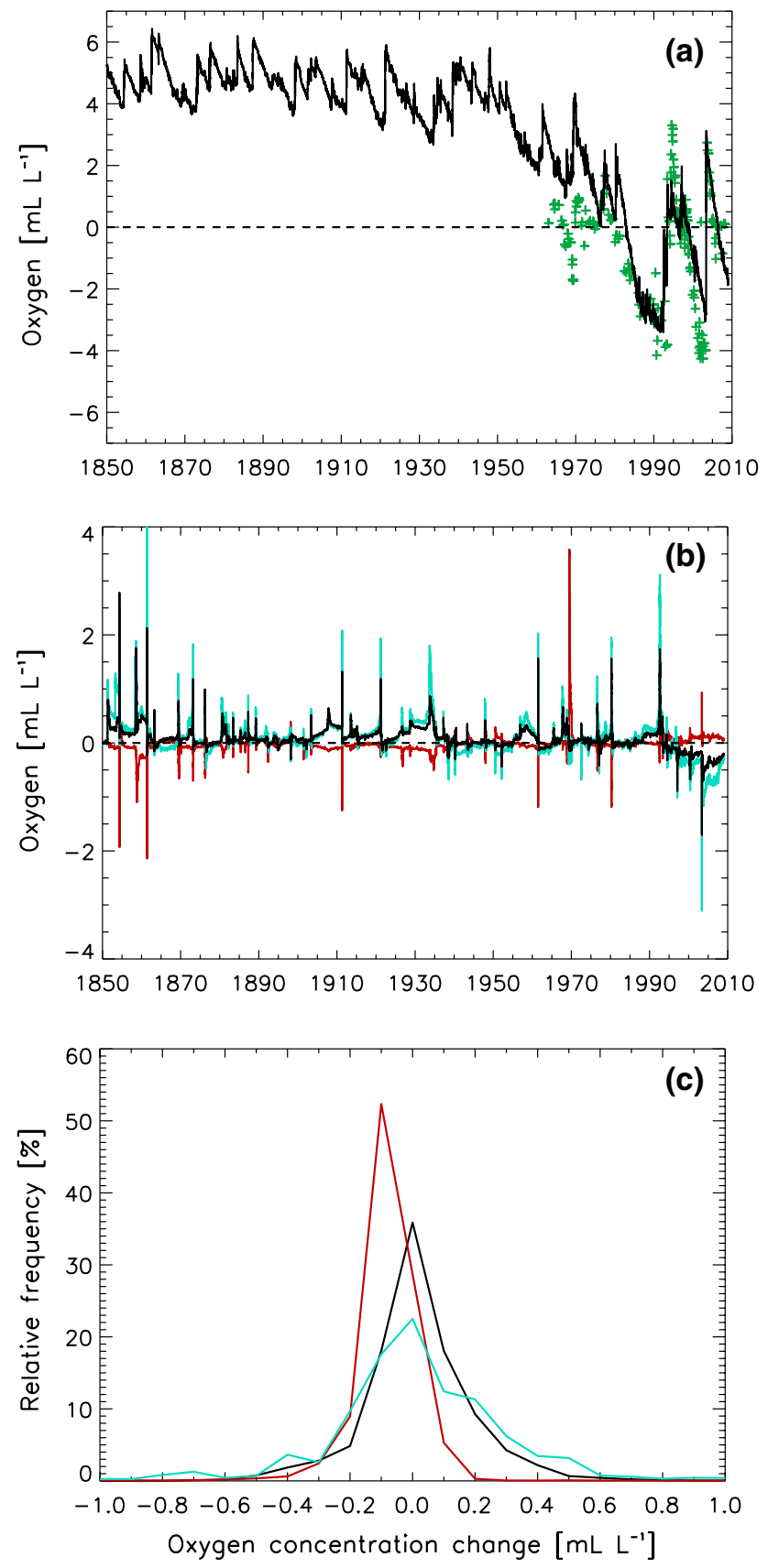

Fig. 3 a Two-daily oxygen concentration (in $\mathrm{mL} \mathrm{L}^{-1}$ ) at Gotland Deep in the reference simulation (black line) and observations in $200 \mathrm{~m}$ (green crosses). b Two-daily bottom oxygen concentration differences (in $\mathrm{mL} \mathrm{L}^{-1}$ ) at Gotland Deep between sensitivity and reference simulations and $\mathbf{c}$ its relative frequencies (in \%): PAST (red line), S50 (black line) and S100 (blue line)

changes as a consequence of increased salt water transports into the Baltic Sea by increasing the amplitude of sea level variations at the lateral boundary in Kattegat. However, for the temporal evolution of bottom salinity, in particular during the first years of the simulation, an e-function is not a good approximation indicating that non-diffusive processes

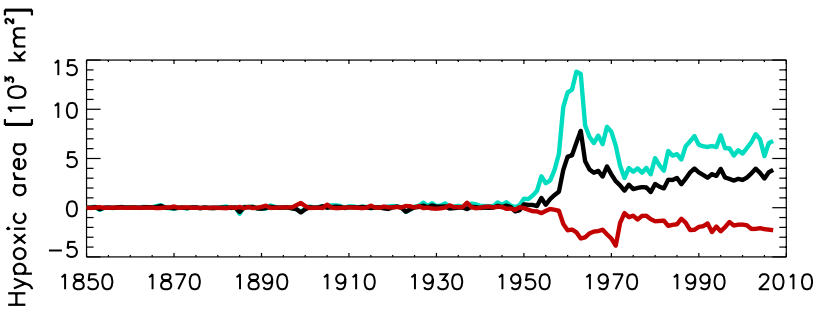

Fig. 4 Annual maximum hypoxic area differences (in $10^{9} \mathrm{~m}^{2}$ ) between sensitivity and reference simulations: PAST (red line), S50 (black line) and S100 (blue line). Differences in hypoxic area are small before 1950 because hypoxia did more or less not occur. Mainly due to intensified agriculture nutrient loads increased in the 1950 s and led to eutrophication with hypoxia as a consequence (Gustafsson et al. 2012)

like advection are important as well. After about 60 years a new quasi steady-state will be reached (Fig. 2). Hence, the relevant time scale for the salinity response to GSLR is relatively large as we anticipated.

Applying a $1 \mathrm{~m}$ higher sea level (S100) causes surface and bottom salinities at Gotland Deep to increase by about 1.3 and $1.8 \mathrm{~g} \mathrm{~kg}^{-1}$ compared to REF, respectively (Table 1; Fig. 2). The corresponding increase in mean salinity averaged for the Baltic Sea including Kattegat amounts to $1.4 \mathrm{~g} \mathrm{~kg}^{-1}$ or $19 \%$. Our results support earlier findings by Gustafsson (2004) who used a process-oriented model to study salinity in the Baltic Sea as function of freshwater supply and mean sea level change. Gustafsson (2004) found that a GSLR of $+1 \mathrm{~m}$ would lead to a sea surface salinity increase of $1 \mathrm{~g} \mathrm{~kg}^{-1}$ in the southern Baltic proper.

According to Table 1, the relationship between salinity and sea level change is approximately linear, indicating that changes in salt transports through the Danish straits alter with the changes in cross section.

Although MBIs usually consist of oxygen-rich winter water (Matthäus and Franck 1992), we found in S50 and S100 only small increases of the mean (median) bottom oxygen concentration at Gotland Deep averaged for the entire period 1850-2008 of about $0.07(0.06)$ and 0.08 (0.04) $\mathrm{mL} \mathrm{L}^{-1}$, respectively (Fig. 3b, c). In S50 oxygen anomalies at the bottom of Gotland Deep amount to up to $2.8 \mathrm{~mL} \mathrm{~L}^{-1}$. Most of the additional oxygen in inflowing water pulses is lost either on the way into the Baltic interior due to diffusion (mixing with oxygen-poor surrounding water) or in the deep water due to oxygen consumption by organic matter degradation and oxidation of earlier reduced compounds (Fig. 3b, c). In agreement with observations (Feistel et al. 2008) the time scale of oxygen depletion at Gotland Deep after an MBI amounts to about 18 months on average under present eutrophication conditions (at least until the 1990s). Hence, in the deep water at Gotland Deep the effect of a $1 \mathrm{~m}$ higher global mean sea level as shown 


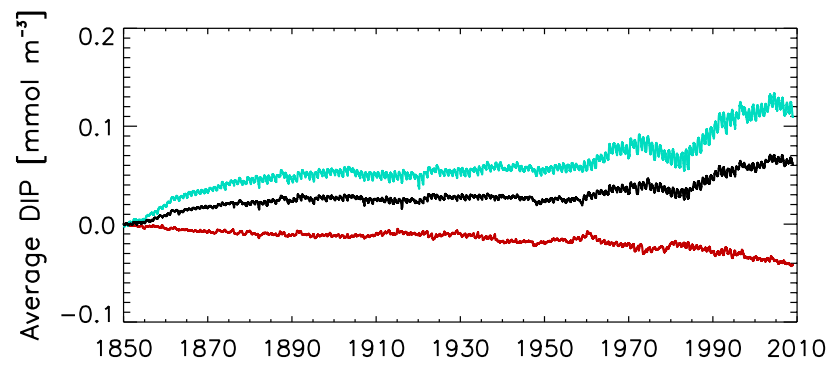

Fig. 5 Two-daily dissolved inorganic phosphorus concentration differences (in $\mathrm{mmol} \mathrm{m}^{-3}$ ) averaged for the entire Baltic Sea between sensitivity and reference simulations: PAST (red line), S50 (black line) and S100 (blue line)

in S100 on oxygen renewal is relatively small on average. Nonetheless, in S50 and S100 mean and median changes in bottom oxygen concentrations are significantly positive whereas in PAST these changes are significantly negative (Fig. 3c). The relative frequency distributions of bottom oxygen concentration changes in S50 and S100 show larger positive extremes compared to PAST.

The sensitivity experiment PAST suggests that during the past century GSLR had an impact on hypoxic area, in particular during the early phase of eutrophication, although the long-term mean effect was relatively small (Fig. 4). According to PAST hypoxic area in 1961 would have been about $8 \%$ smaller than observed if the global mean sea level was $0.24 \mathrm{~m}$ lower than today (Table 1 ). In the sensitivity experiments, S50 and S100, we found that since the 1950s hypoxic areas increase considerably (Fig. 4). The increase in S50 and S100 is largest during the early phase of the eutrophication period with about 19 and $43 \%$ in 1961, respectively (Table 1). During 1988-2007 changes in hypoxic area are relatively smaller with about 4 and $7 \%$ in S50 and S100, respectively. Because of higher salinity in the deep water the halocline in the sensitivity experiment is shallower and stratification larger compared to REF (Fig. 2). Hence, in bottom areas along the slopes, that are not directly affected by saltwater inflows and that are dropped below the halocline, the vertical flux of oxygen from the surface to the bottom is reduced causing oxygen depletion. A similar effect can be seen from observations during decades when MBIs occur more frequently compared to stagnation periods without MBIs (Matthäus et al. 2008). For instance during 1976-1994, a period with few MBIs, the deep water below $150 \mathrm{~m}$ at Gotland Deep was on average anoxic. But the oxygen concentration in and below the halocline, in the depth interval of $65-125 \mathrm{~m}$, was higher compared to the earlier period 1959-1976 with many MBIs and the depth of hypoxia deepened from 75 to $90 \mathrm{~m}$ (Eilola 1998). Hence, hypoxic area of the Baltic proper decreased during the stagnation period 1983-1992 (Conley et al. 2002).
According to PAST the DIP content in 1988-2007 would have been about $3 \%$ smaller than observed if the global mean sea level was $0.24 \mathrm{~m}$ lower than today (Table 1; Fig. 5). The relative impact of GSLR on the DIP pool is larger during the oligotrophic period before 1950 than during the eutrophic period after 1950 (not shown). These results suggest that approximately after the 1960s the total change in the DIP pool was dominated by increasing eutrophication and the GSLR of +0.24 m played only a minor role.

As under anoxic conditions internal phosphorus fluxes from the sediments increase (e.g., Eilola et al. 2009), in S50 and S100 the volume integrated dissolved inorganic phosphorus (DIP) contents in the water column of the entire Baltic Sea increase during 1988-2007 relative to REF by about 5 and $9 \%$, respectively (Table 1; Fig. 5). In the sediments of the shallow Baltic Sea, organic phosphorus is transformed to inorganic phosphorus and on long time scales phosphorus is even removed from the biogeochemical cycling in the water column (Eilola et al. 2009). It is proposed that a fraction of the deposited organic phosphorus is transformed to mineral bound inorganic phosphorus (e.g., Almroth-Rosell et al. 2015). Phosphorus can be released from the sediment pool to the overlaying water or become adsorbed from the water into the sediment depending on the oxygen concentrations. In case of anoxic conditions, phosphorus is released from the sediments and under oxic conditions the flux is reversed. For details of the relevant sediment chemistry, the reader is referred to AlmrothRosell et al. (2015). In the SCOBI version of the present study, a salinity and oxygen dependent parameterization of the phosphorus release capacity is used to calculate the sediment-water fluxes (Eilola et al. 2009).

The increased phosphate concentration in the euphotic zone results in increased primary production (not shown). In addition, the risk for the occurrence of nitrogen-fixing cyanobacteria blooms during summer might increase enhancing the so-called "vicious" cycle that amplifies eutrophication in the Baltic Sea (Vahtera et al. 2007; Conley et al. 2009). Our findings are qualitatively similar to simulation results with a dredged Sound using two different coupled physical-biogeochemical models (Gustafsson et al. 2008).

\section{Discussion}

\subsection{Shortcoming of the experimental set-up}

In this study, three sensitivity simulations are analyzed to investigate the impact of (1) past GSLR, (2) an ensembleaverage scenario for GSLR of $+0.5 \mathrm{~m}$, and (3) a high-end scenario for GSLR of $+1 \mathrm{~m}$ on biogeochemical cycling 
assuming present eutrophication conditions. We cover with our experiments the whole range of future sea level evolutions until 2100 as projected by Church et al. (2013). However, the simulations are idealized sensitivity experiments with added time-independent sea level anomalies instead of transient simulations with continuously rising sea level. Although our idealized experiments are neither plausible scenario simulations for future climate nor realistic reconstructions of past climate, respectively, they have the advantage that we were able to study steady-state conditions and response time scales without overlying long-term trends.

\subsection{Model shortcomings}

Model response to changing GSLR is assumed to be realistic because RCO-SCOBI was earlier thoroughly evaluated. For instance, the evolution of salinity and the frequency of MBIs in REF were evaluated by Schimanke and Meier (2016) who found that the model gives reasonably good results compared to observations although the atmospheric and hydrological forcing fields are only reconstructed (Gustafsson et al. 2012). However, salinity of the deep water at Gotland Deep is somewhat lower than in observations.

Also the evolution of oxygen is well simulated (Fig. 3a) but modeled oxygen concentrations in the Gotland Deep water during the 1960s are somewhat too high. This seems to be a common problem among historical simulations driven by reconstructed forcing (Meier et al. 2012) indicating either a general problem of biogeochemical models under oligotrophic conditions or unrealistically high nutrient loads during the 1950s and 1960s in the reconstruction.

Simulated and from observations derived hypoxic and anoxic areas have been analyzed by Väli et al. (2013). They found only small model biases when they applied the same methodology for their calculations as was applied for observations.

Finally, volume and salt water flows through the Danish straits as function of sea level changes have previously been evaluated by Meier et al. (2003). They found that the volume transports through one of the connecting straits, the Sound (Fig. 1), are very well simulated compared to volume transports calculated from ADCP measurements during 1992 and 1993 indicating that in RCO the flow resistance to sea level changes is well calibrated (Meier et al. 2003). As also volume changes in the Baltic Sea are realistically simulated (compared to observations from tide gauges, e.g. at Landsort station), the volume flows through the second connecting strait, the Great Belt, where the calculation of transports from ADCP measurements is more difficult due to the more complicated topography, are consequently simulated realistically as well. For the MBI in
1993 Meier et al. (2003) showed that simulated volume and salt transports through each of the connecting straits are within the error bar of corresponding figures estimated from available observations during that period.

Nevertheless, the simulated response to GSLR might be biased due to model deficiencies. In particular, changes in halocline depth and halocline strength are simulated differently in different models (Meier et al. 2011). Further, sediment-water fluxes of nutrients are not well known (Eilola et al. 2011). Hence, we propose to investigate sedimentwater fluxes of phosphorus in more detail to reduce uncertainty of simulated changes in phosphorus cycling. For this purpose, Almroth-Rosell et al. (2015) recently developed a new sediment module that takes oxygen penetration depths (OPDs) and inorganic phosphorus pools within the vertically integrated sediment model into account. Although the new sediment module may improve the simulated sediment-water fluxes, more research is still needed.

\subsection{Other drivers of hypoxia}

According to Schrum et al. (2016) GSLR is approximately representative for the North Sea region because around $70 \%$ of the world's coastline is located in an area with a projected sea level rise that falls within a $20 \%$ range of the GSLR (Church et al. 2013). Further, it was concluded that future changes in wind speed and storm surge height over the North Sea are either statistically insignificant or relatively small (e.g., Christensen et al. 2015; Meier 2015; Schrum et al. 2016). There is also no evidence of significant trends in annual wind statistics since the nineteenth century (Rutgersson et al. 2015). These findings support our assumptions that GSLR may be applied together with unchanged sea level variations at the northern boundary in Kattegat.

However, a northeastward shift in storm tracks and an increase in the deep lows over Scandinavia were found (e.g. Lehmann et al. 2011; Feser et al. 2014; Rutgersson et al. 2015). If these atmospheric changes in extreme conditions persist in the future, this may be an additional factor potentially affecting MBIs and consequently hypoxia. Although Schimanke et al. (2014) concluded that atmospheric variability favorable for MBIs may intensify in future climate, there is nevertheless no strong evidence from available scenario simulations (which do not take GSLR into account) that intensity or frequency of saltwater inflows may change significantly (Meier 2015). Therefore, in future climate GSLR and changes in river runoff to the Baltic Sea, as suggested by Meier et al. (2006), might be the two dominating and competing drivers of the water exchange between North Sea and Baltic Sea. However, the role of GSLR for the future water exchange is still unclear because of the large uncertainty of projected GSLR. In addition, changes 
in frequency and intensity of small and medium inflows and MBIs cannot be ruled out.

Eilola et al. (2014) showed with the help of tracer experiments that the overall direct impact of MBIs on the annual uplift of nutrients from below the halocline to the surface waters is small because vertical transports are comparably large also during periods without MBIs. Further, they suggested that phosphorus released from the sediments between 60 and $100 \mathrm{~m}$ depth in the eastern Gotland Basin may contribute to eutrophication. These results support our findings that the direct impact of GSLR like increased frequency and intensity of MBIs on the phosphorus cycling is small. Instead, a shallower halocline and extended hypoxic areas due to GSLR are the important factors that affect the reduced phosphorus retention in the sediments.

\subsection{Outlook}

We propose to perform new multi-model ensemble scenario simulations for the Baltic Sea taking GSLR and also new, improved regional and global models, and the latest greenhouse gas emission (RCPs) and nutrient load scenarios into account. Further, new evaluation data sets and more realistic initial conditions may help to improve scenario simulations.

\section{Conclusions}

Our model simulations suggest that GSLR will cause increases in (1) frequency and magnitude of saltwater inflows, (2) salinity and (3) phosphate concentrations in the Baltic Sea as a direct or indirect consequence of increased cross sections in the Danish straits, and will contribute to (4) increased hypoxia and anoxia amplifying the previously reported future impacts of increased external nutrient loads due to increased runoff, reduced oxygen flux from the atmosphere to the ocean and intensified internal nutrient cycling due to increased water temperatures in future climate (Meier et al. 2011). Although GSLR will cause more intense inflows of high-saline, oxygen-rich water, hypoxic bottom areas will increase because of increased stratification. However, the impact of historical GSLR since 1850 on hypoxic area and mean DIP concentrations was small and long-term changes in both variables were mainly governed by changes in anthropogenic nutrient loads. Also future GSLR will very likely have only a small effect on biogeochemical cycles when a projected ensemble-mean GSLR of about $+0.5 \mathrm{~m}$ until the end of the twenty-first century and present-day eutrophication status is assumed. However, applying a high-end scenario with a GSLR of $+1 \mathrm{~m}$ will result in an increase in mean salinity of about $19 \%$ and in increased hypoxic bottom area of about $43 \%$ in maximum.
Hence, GSLR should be considered as potential driver in climate change scenario simulations for the Baltic Sea and other coastal seas with similar hydrographical conditions.

Acknowledgments The research presented in this study is part of the Baltic Earth program (Earth System Science for the Baltic Sea region, see http://www.baltic.earth) and was funded by the Swedish Research Council for Environment, Agricultural Sciences and Spatial Planning (FORMAS) within the project "Impact of accelerated future global mean sea level rise on the phosphorus cycle in the Baltic Sea" (Grant No. 214-2009-577), by the Stockholm University's Strategic Marine Environmental Research Funds "Baltic Ecosystem Adaptive Management (BEAM)", and by the Swedish Research Council (VR) within the project "Reconstruction and projecting Baltic Sea climate variability 1850-2100" (Grant No. 2012-2117). Additional financial support from the Danish Agency for Science, Technology and Innovation (\# 09-067259/DSF) is acknowledged. We thank three anonymous reviewers for their comments that helped to improve the manuscript.

Open Access This article is distributed under the terms of the Creative Commons Attribution 4.0 International License (http://creativecommons.org/licenses/by/4.0/), which permits unrestricted use, distribution, and reproduction in any medium, provided you give appropriate credit to the original author(s) and the source, provide a link to the Creative Commons license, and indicate if changes were made.

\section{References}

Almroth-Rosell E, Eilola K, Hordoir R, Meier HEM, Hall P (2011) Transport of fresh and resuspended particulate organic material in the Baltic Sea-a model study. J Mar Syst 87:1-12. doi:10.1016/j.jmarsys.2011.02.005

Almroth-Rosell E, Eilola K, Kuznetsov I, Hall P, Meier HEM (2015) A new approach to model oxygen dependent benthic phosphate fluxes in the Baltic Sea. J Mar Syst 144:127-141. doi:10.1016/j. jmarsys.2014.11.007

Arneborg L (2016) Comment on "Influence of sea level rise on the dynamics of salt inflows in the Baltic Sea" by R. Hordoir, L. Axell, U. Löptien, H. Dietze, and I. Kuznetsov. J Geophys Res Oceans 121:2035-2204. doi:10.1002/2015JC011451

BACC II author team (2015) Second assessment of climate change for the Baltic Sea basin. Reg Clim Stud Springer, Berlin

Belkin I (2009) Rapid warming of large marine ecosystems. Prog Oceanogr 81:207-213. doi:10.1016/j.pocean.2009.04.011

Bergström S, Carlsson B (1994) River runoff to the Baltic Sea: 19501990. Ambio 23:280-287

Christensen OB, Kjellström E, Zorita E (2015) Projected change: atmosphere. In: BACC II author team, second assessment of climate change for the Baltic Sea Basin. Reg Clim Stud Springer Berlin Chapter 11, pp 217-233

Church JA, Clark PU, Cazenave A, Gregory JM, Jevrejeva S, Levermann A, Merrifield MA, Milne GA, Nerem RS, Nunn PD, Payne AJ, Pfeffer WT, Stammer D, Unnikrishnan AS (2013) Sea level change. In: IPCC, climate change 2013: the physical science basis, working group I contribution to the fifth assessment report (AR5). Intergovernmental panel on climate change, chapter 13, pp 1137-1216

Conley DJ (2012) Ecology: save the Baltic Sea. Nature 486:463-464

Conley DJ, Humborg C, Rahm L, Savchuk OP, Wulff F (2002) Hypoxia in the Baltic Sea and basin-scale changes in phosphorus biogeochemistry. Environ Sci Technol 36:5315-5320. doi:10.1021/es025763w 
Conley DJ, Björck S, Bonsdorff E, Carstensen J, Destouni G et al (2009) Hypoxia-related processes in the Baltic Sea. Environ Sci Technol 43(10):3412-3420. doi:10.1021/es802762a

Döscher R, Meier HEM (2004) Simulated sea surface temperature and heat fluxes in different climates of the Baltic Sea. Ambio 33:242-248

Eilola K (1998) Oceanographic studies of the dynamics of freshwater, oxygen and nutrients in the Baltic Sea. Ph.D. thesis A30, Dept of Oceanography, Göteborg University, Sweden, pp 1-22

Eilola K, Meier HEM, Almroth E (2009) On the dynamics of oxygen, phosphorus and cyanobacteria in the Baltic Sea; a model study. $\mathrm{J}$ Mar Syst 75:163-184. doi:10.1016/j.jmarsys.2008.08.009

Eilola K, Gustafson BG, Kuznetsov I, Meier HEM, Neumann T et al (2011) Evaluation of biogeochemical cycles in an ensemble of three state-of-the-art numerical models of the Baltic Sea. J Mar Syst 88:267-284. doi:10.1016/j.jmarsys.2011.05.004

Eilola K, Almroth-Rosell E, Meier HEM (2014) Impact of saltwater inflows on phosphorus cycling and eutrophication in the Baltic Sea. A 3D model study. Tellus A 66:23985. doi:10.3402/tellusa. v66.23985

Ekman M (1996) A consistent map of the postglacial uplift of Fennoscandia. Terra Nova 8:158-165. doi:10.1111/j.1365-3121.1996. tb00739.x

Feistel R, Nausch G, Wasmund N (eds) (2008) State and evolution of the Baltic Sea, 1952-2005. A detailed 50-year survey of meteorology and climate, physics, chemistry, biology, and marine environment. Wiley, Hoboken

Feser F, Barcikowska M, Krueger O, Schenk F, Weisse R, Xia L (2014) Storminess over the North Atlantic and Northwestern Europe-a review. Quart J R Meteorol Soc 141:350-382. doi:10.1002/qj.2364

Fischer H, Matthäus W (1996) The importance of the Drogden Sill in the Sound for major Baltic inflows. J Mar Syst 9:137-157

Gornitz V (1995) Monitoring sea level changes. Clim Change 31:515-544. doi:10.1007/BF01095160

Graham LP (1999) Modeling runoff to the Baltic Sea. Ambio $27: 328-334$

Gräwe U, Naumann M, Mohrholz V, Burchard H (2015) Anatomizing one of the largest saltwater inflows into the Baltic Sea in December 2014. J Geophys Res Oceans 120:7676-7697. doi:10.1002/2 015JC011269

Gustafsson BG (2004) Sensitivity of Baltic Sea salinity to large perturbations in climate. Clim Res 2:237-251. doi:10.3354/cr027237

Gustafsson BG, Andersson HC (2001) Modeling the exchange of the Baltic Sea from the meridional atmospheric pressure difference across the North Sea. J Geophys Res 106:19731-19744

Gustafsson BG, Westman P (2002) On the causes for salinity variations in the Baltic Sea during the last 8500 years. Paleoceanography 17:12-2-12-14. doi:10.1029/2000PA000572

Gustafsson BG, Meier HEM, Savchuk OP, Eilola K, Axell L, Almroth E (2008) Simulation of some engineering measures aiming at reducing effects from eutrophication of the Baltic Sea. Report Series C82, Earth Sciences Centre, Göteborg University, Sweden

Gustafsson BG, Schenk F, Blenckner T, Eilola K, Meier HEM, Müller-Karulis B, Neumann T, Ruoho-Airola T, Savchuk OP, Zorita E (2012) Reconstructing the development of Baltic Sea eutrophication 1850-2006. Ambio 41:534-548. doi:10.1007/ s13280-012-0318-x

Hansson DC, Eriksson C, Omstedt A, Chen D (2011) Reconstruction of river runoff to the Baltic Sea, AD 1500-1995. Int J Clim 31:696-703. doi:10.1002/joc.2097

Hilton TW, Najjar RG, Zhong L, Li M (2008) Is there a signal of sea level rise in Chesapeake Bay salinity? J Geophys Res 113:C09002. doi:10.1029/2007JC004247

Hordoir R, Axell L, Löptien U, Dietze H, Kuznetsov I (2015) Influence of sea level rise on the dynamics of salt inflows in the Baltic Sea. J Geophys Res Oceans 120:6653-6668. doi:10.1002/2014JC010642
IPCC (2013) Climate change 2013: the physical science basis, working group I contribution to the fifth assessment report (AR5). Intergovernmental panel on climate change. http:// www.ipcc.ch

Lass H-U, Matthäus W (1996) On temporal wind variations forcing salt water inflows into the Baltic Sea. Tellus 48A:663-671

Lehmann A, Getzlaff K, Harlaß J (2011) Detailed assessment of climate variability in the Baltic Sea area for the period 1958 to 2009. Clim Res 46:185-196. doi:10.3354/cr00876

Matthäus W, Franck H (1992) Characteristics of major Baltic inflows-a statistical analysis. Cont Shelf Res 12:1375-1400

Matthäus W, Dietwart N, Feistel R, Nausch G, Mohrholz V, Lass H-U (2008) The inflow of highly saline water into the Baltic Sea. In: Feistel R, Nausch G, Wasmund N (eds) State and evolution of the Baltic Sea 1952-2005. Wiley, Hoboken

Meier HEM (2005) Modeling the age of Baltic Sea water masses: quantification and steady state sensitivity experiments. J Geophys Res 110:C02006. doi:10.1029/2004JC002607

Meier HEM (2015) Projected change: marine physics. In: BACC II author team, second assessment of climate change for the Baltic Sea Basin. Reg Clim Stud Springer Berlin Chapter 13, pp 243-252

Meier HEM, Kauker F (2003) Modeling decadal variability of the Baltic Sea: 2. Role of freshwater inflow and large-scale atmospheric circulation for salinity. J Geophys Res 108:3368. doi:10. 1029/2003JC001799

Meier HEM, Döscher R, Faxén T (2003) A multiprocessor coupled ice-ocean model for the Baltic Sea: application to salt inflow. J Geophys Res 108:3273. doi:10.1029/2000JC000521

Meier HEM, Kjellström E, Graham P (2006) Estimating uncertainties of projected Baltic Sea salinity in the late 21st century. Geophys Res Lett 33:L15705. doi:10.1029/2006GL026488

Meier HEM, Andersson HC, Eilola K, Gustafsson BG, Kuznetsov I, Müller-Karulis B, Neumann T, Savchuk OP (2011) Hypoxia in future climates: a model ensemble study for the Baltic Sea. Geophys Res Lett 38:L24608. doi:10.1029/2011GL049929

Meier HEM, Andersson HC, Arheimer B, Blenckner T, Chubarenko B, Donnelly C, Eilola K, Gustafsson BG, Hansson A, Havenhand J, Höglund A, Kuznetsov I, MacKenzie B, Müller-Karulis B, Neumann T, Niiranen S, Piwowarczyk J, Raudsepp U, Reckermann M, Ruoho-Airola T, Savchuk OP, Schenk F, Weslawski JM, Zorita E (2012) Comparing reconstructed past variations and future projections of the Baltic Sea ecosystem-first results from multi-model ensemble simulations. Environ Res Lett 7:034005. doi:10.1088/1748-9326/7/3/034005

Mohrholz V, Naumann M, Nausch G, Krüger S, Gräwe U (2015) Fresh oxygen for the Baltic Sea-an exceptional saline inflow after a decade of stagnation. J Mar Syst 148:152-166. doi:10.1016/j.jmarsys.2015.03.005

Neumann T, Eilola K, Gustafsson BG, Müller-Karulis B, Kuznetsov I, Meier HEM, Savchuk OP (2012) Extremes of temperature, oxygen and blooms in the Baltic Sea in a changing climate. Ambio 41:574-585. doi:10.1007/s13280-012-0321-2

Omstedt A, Edman M, Claremar B, Frodin P, Gustafsson E, Humborg C, Hägg H, Mörth M, Rutgersson A, Schurger G, Smith B, Wällstedt T, Yurova A (2012) Future changes in the Baltic Sea acidbase $(\mathrm{pH})$ and oxygen balances. Tellus B 64:19586. doi:10.3402/ tellusb.v64i0.19586

Pfeffer WT, Harper JT, O'Neet S (2008) Kinematic constraints on glacier contributions to 21 st-century sea-level rise. Science 321:1340-1343. doi:10.1126/science.1159099

Quante M, Colijn F (eds) (2016) North Sea region climate change assessment. Springer, Berlin (in press)

Radtke H, Neumann T, Voss M, Fennel W (2012) Modeling pathways of riverine nitrogen and phosphorus in the Baltic Sea. J Geophys Res 117:C09024. doi:10.1029/2012JC008119 
Rahmstorf S (2007) A semi-empirical approach to projecting future sea-level rise. Science 315:368-370. doi:10.1126/ science. 1135456

Ruoho-Airola T, Eilola K, Savchuk OP, Parviainen M, Tarvainen V (2012) Atmospheric nutrient input to the Baltic Sea for 18502006: a reconstruction from modeling results and historical data. Ambio 41:549-557. doi:10.1007/s13280-012-0319-9

Rutgersson A, Jaagus J, Schenk F, Stendel M, Bärring L, Briede A, Claremar B, Hanssen-Bauer I, Holopainen J, Moberg A, Nordli $\varnothing$, Rimkus E and Wibig J (2015) Recent change: atmosphere. In: BACC II author team, second assessment of climate change for the Baltic Sea Basin. Reg Clim Stud Springer Berlin Chapter 4, pp 69-98

Savchuk OP, Wulff F, Hille S, Humborg C, Pollehne F (2008) The Baltic Sea a century ago-a reconstruction from model simulations, verified by observations. J Mar Syst 74:485-494

Savchuk OP, Gustafsson BG, Rodriguez-Medina M, Sokolov AV, Wulff FV (2012) Nutrient loads to the Baltic Sea 1970-2006, Baltic Nest Institute technical report no. 5, Stockholm

Schenk F, Zorita E (2012) Reconstruction of high resolution atmospheric fields for Northern Europe using analog-upscaling. Clim Past 8:1681-1703. doi:10.5194/cp-8-1681-2012

Schimanke S, Meier HEM (2016) Decadal to centennial variability of salinity in the Baltic Sea. J Clim. doi:10.1175/JCLI-D-15-0443.1

Schimanke S, Dieterich C, Meier HEM (2014) An algorithm based on sea-level pressure fluctuations to identify major Baltic inflow events. Tellus A 66:23452. doi:10.3402/tellusa.v66.23452
Schrum C, Lowe J, Meier HEM (2016) Projected change: North Sea. In: Quante M, Colijn F (eds) North Sea region climate change assessment. Springer, Berlin

Sonnenborg TO (2015) Projected change: hydrology. In: BACC II author team, second assessment of climate change for the Baltic Sea Basin. Reg Clim Stud Springer Berlin Chapter 12, pp 235-241

Vahtera E, Conley DJ, Gustafsson BG, Kuosa H, Pitkänen H, Savchuk OP, Tamminen T, Viitasalo M, Voss M, Wasmund N, Wulff F (2007) Internal ecosystem feedbacks enhance nitrogen-fixing cyanobacteria blooms and complicate management in the Baltic Sea. Ambio 36:186-194. doi:10.1579/0044-7447

Väli G, Meier HEM, Elken J (2013) Simulated halocline variability in the Baltic Sea and its impact on hypoxia during 1961-2007. J Geophys Res 118:6982-7000. doi:10.1002/2013JC009192

Zillén L, Conley DJ (2010) Hypoxia and cyanobacteria blooms-are they really natural features of the late Holocene history of the Baltic Sea? Biogeosciences 7:2567-2580. doi:10.5194/bg-7-2567-2010

Zillén L, Conley DJ, Andrén T, Andrén E, Björck S (2008) Past occurrences of hypoxia in the Baltic Sea and the role of climate variability, environmental change and human impact. Earth Sci Rev 91:77-92. doi:10.1016/j.earscirev.2008.10.001 